\title{
Lectio praecursoria
}

\section{Ammatillinen kuunteleminen oikeudellisessa kontekstissa}

\author{
Sanna Ala-Kortesmaa \\ viestintäkouluttaja, FT \\ Tampereen yliopisto \\ sannaalakortesmaa@gmail.com
}

Lectio praecursoria puheviestinnän väitöskirjaksi tarkoitetun tutkimuksen Professional listening in the legal context tarkastustilaisuudessa Tampereen yliopistossa 23.10.2015. Vastaväittäjänä toimi apulaisprofessori Laura Janusik (Rockhurst University, Missouri, USA) ja kustoksena professori Pekka Isotalus.

Kuunteleminen on juurtunut syvälle kaikkiin kulttuureihin. Sillä on aina ollut useita tehtäviä: kuuntelemalla on muun muassa osoitettu empatiaa, otettu vastaan sukupolvelta toiselle siirtyvää tietoa ja arvioitu kriittisesti puhujan kertomaa asiaa. Kuunteleminen on keskeinen osa yhteistä vuorovaikutustamme - on miltei mahdotonta olla kuuntelematta, koska kuunteleminen tekee vuorovaikutuksesta merkityksellistä. Yleisesti sanottuna kuunteleminen on tärkeä henkilökohtainen, ammatillinen ja akateeminen taito.

Kuuntelemista on kuitenkin pidetty erityisesti työelämässä jonkinlaisena synnynnäisenä tai automaattisesti omaksuttuna kykynä, johon ei tarvitse erityisesti keskittyä. Tämä näkemys on viime aikoina alkanut onneksi muuttua, sillä on ammatteja, joissa kuuntelemistaidot ovat kriittisessä asemassa. Esimerkiksi suomalaisessa oikeussaliympäristössä kuuntelemisen katsotaan olevan yksi tärkeimmistä työkaluista, joiden avulla oikeus toteuttaa suullisuuden, välittömyyden ja keskittämisen periaatteita. Onnistunut kuunteleminen on avainasemassa, kun vuorovaikutuksen tavoitteena on asiallisesti oikea ratkaisu toiminnan selkeyttä, havainnollisuutta ja ymmärrettävyyttä unohtamatta. Tuomarin ja asianajajan ammatit ovat 
erinomaisia esimerkkejä ammateista, joissa vuorovaikutus- ja erityisesti kuuntelemisosaaminen nousee tärkeydeltään ammattisisältöjen hallitsemisen rinnalle, kun pohditaan työssäonnistumista ja työn tavoitteiden saavuttamista.

Työhyvinvoinnin ja työssäjaksamisen merkitystä saatetaan pitää vähäisenä, kun mietitään juristin ammattia. Jotkut saattavat jopa väittää oikeusalan ammattilaisten työstään saaman rahallisen korvauksen karkottavan tyytymättömyyden, stressin ja väsymyksen. Kaikki juristit eivät kuitenkaan työskentele paremmin palkatulla yksityisellä sektorilla, ja totuus on, että vain työssään hyvinvoiva ihminen pystyy suoriutumaan tehtävistään esimerkillisesti. Kuka tahansa meistä voi joskus joutua syystä tai toisesta kääntymään juristin puoleen, ja koska päätöksillä ja sopimuksilla, joita oikeusistuimissa tehdään, voi olla kauaskantoisia vaikutuksia, on kaikkien etu, että asioita ajavat parhaassa terässään olevat alansa ammattilaiset.

Viime aikoina on puhuttu paljon siitä, miten vuorovaikutuksella voidaan vaikuttaa työhyvinvointiin. Muoti-ilmaisuja ovat olleet muun muassa viestinnän dialogisuus ja tehokkuus. Tällöin on usein viitattu kuuntelemistaitoihin, mikä on osaltaan saattanut edistää kuuntelemisen hahmottamista tiedostettavaksi ja harjoitettavissa olevaksi taidoksi. Useimmissa tutkimuksissa fokus on tosin ollut yleensä siinä, kuinka muiden kuuntelemistaidot voivat parantaa omaa työhyvinvointia. Vaikka kokemus siitä, miten muut kuuntelevat itseä, on tärkeä oman hyvinvoinnin kannalta, tällaiseen käyttäytymisen arvioinnille perustuvaan kuuntelemisosaamisen tulkintaan sisältyy suuri väärintulkitsemisen vaara.

Kun ammattilaiset pääsevät itse aktiivisesti miettimään, miten heidän omat vuorovaikutustaitonsa palvelevat heidän omia työroolejaan ja työssäjaksamistaan, toisen käytöksen tarkkailemisesta johtuvat mahdolliset väärinymmärrykset vähenevät. Usko omiin taitoihin lisääntyy, kun niistä tullaan tietoisiksi ja omaa kokemusta päästään hyödyntämään monipuolisesti. Kuuntelemisosaamista, sen systemaattista rakentumista ja sen vaikutusta työhyvinvointiin on kokonaisuutena tarkasteltu yllättävän vähän. Itseäni on askarruttanut muun muassa se, miten samassa ammatissa työskentelevien ihmisten kuuntelemisosaaminen voi olla niin eri tasoilla, vaikka heidän asemaansa pääsy on edellyttänyt suunnilleen samanlaista koulutusta ja kokemusta, ja se, miksi toiset kokevat kuuntelemisen olevan kiinnostavimpia asioita työssään, kun taas toiset uupuvat jo kuuntelemista ajatellessaan. Nämä pohdinnat johtivat minut väitöskirjani aiheeseen, joka käsittelee ammatillista kuuntelemista oikeudellisessa kontekstissa. 


\section{Tutkimus}

Tätä väitöskirjatutkimusta ohjasi ensisijaisesti halu ymmärtää kuuntelemista ilmiönä, joka lähtee yksilöstä mutta tulee havaittavaksi vasta vuorovaikutuksessa erilaisina viestintätekoina. Viestintätekojen muodostama viestintäkäyttäytyminen vaikuttaa osaltaan siihen, onko vuorovaikutus kestävää ja reaktiokykyistä. Kun kuunteleminen on tarkoituksenmukaista, informaation kerääminen, arviointi, ja organisointi sekä informaatioon reagointi asianmukaisella tavalla kumpuavat työtehtävän asettamasta tavoitteesta. Kuuntelija ei ole vain passiivinen vuorovaikutukseen osallistuja, vaan hän kantaa oman vastuunsa vuorovaikutuksen onnistumisesta. Tällä kuuntelijan vastuulla voidaan nähdä olevan yhteys yksilön kokemuksiin omasta työssäjaksamisestaan.

Tällä laadullisella tutkimuksella oli neljä keskeistä tavoitetta. Kahta ensimmäistä niistä eli ammatillisesta näkökulmasta optimaalista kuuntelemista ja ammatillisen kuuntelemisosaamisen ulottuvuuksia lähestyttiin analysoimalla aineistoa teorialähtöisesti. Näitä tavoitteita lähestyttiin relationaalisen dialektiikan teorian avulla sekä hyödyntämällä yleisen kuuntelemisosaamisen ulottuvuuksia kuvaavaa teoriarakennetta, jolloin aineistosta nousevat tutkimustulokset täydensivät teoreettista käsitystä tutkituista asioista. Erityisesti Leslie Baxterin sekä Andrew Wolvinin ja Carolyn Coakleyn ajattelu ja heidän rakentamansa teoreettiset mallit vaikuttivat omaan lähestymistapaani. Kahta viimeistä tavoitetta eli dialogisen kuuntelemisen käyttöä ammatillisissa vuorovaikutussuhteissa ilmenevien jännitteiden hallinnassa ja minäpystyvyyden käyttöä subjektiivisen työhyvinvoinnin edistämisessä puolestaan lähestyttiin aineistolähtöisesti Leslie Baxterin ja Barbara Montgomeryn kuvaileman vuorovaikutussuhteen dialektiikan ja Albert Banduran sosio-kognitiivisen teoreettisen viitekehyksen vaikutaessa taustalla.

Tutkimusta varten haastateltiin 25 suomalaista tuomaria, ja kirjallista aineistoa kerättiin 27 suomalaiselta ja 76 amerikkalaiselta asianajajalta. Kahden ammattiryhmän valintaa puolsi se, että näin saatiin kerättyä mahdollisimman kattava kuva oikeudellisessa ympäristössä tarvittavasta kuuntelemisesta, koska tutkimukseen osallistuneiden erilaiset toimenkuvat toivat analysoitaviksi sekä horisontaalisesti eli samalla hierarkisella tasolla että vertikaalisesti eli eri hierarkiset tasot ylittävällä tasolla vaadittavan kuuntelemisosaamisen. Aineistoa analysoitiin Glaserin ja Straussin kehittämän Grounded Theory -menetelmän avulla, mikä mahdollisti ilmiöiden monipuolisen tutkimisen ja teorian kehittämisen aineistosta löytyvien havaintojen, niiden koodauksen ja järjestämisen avulla. 


\section{Tutkimuksen tavoitteita ja niiden arviointia}

Tutkimuksen ensimmäiseen tavoitteeseen eli optimaaliseen kuuntelemiseen relationaalisen dialektiikan ja sosio-kognitiivisen teorian viitekehyksessä liittyvät tulokset osoittavat, että suomalaiset tuomarit määrittelevät työssään tapahtuvan, optimaaliseen työsuoritukseen tähtäävän kuuntelemisen optimaalisen kuuntelijan käsitteen kautta. Heidän mukaansa erityisen hyvä tuomarikuuntelija on suuntautunut viestin sisältöön ja ymmärtää kuuntelemisen aktiivisena, dialogisena prosessina. Samalla he kuitenkin korostivat, ettei heillä ole antaa mitään virallista, selkeää määritelmää optimaalisesta kuuntelemiskäyttäytymisestä, vaan ratkaisut, joita he tekevät kuuntelemiskäyttäytymiseensä liittyvien itsesäätelystrategioiden suhteen, perustuvat niin sanottuun hiljaiseen tietoon, joka heille on muodostunut työkokemuksen myötä. Nämä käytetyt strategiat voidaan jakaa Banduran sosio-kognitiivisessa teoriassa esitettyihin henkilökohtaisen toimijuuden (personal agency) ja kollektiivisen toimijuuden (collective agency) strategioihin. Vaikka kansallisella viestintäkulttuurilla näytti olevan merkittävä vaikutus siihen, mihin juristit keskittyvät kuuntelemisessaan - suomalaisten juristien kuunteleminen on suuntautunut enemmän sisältöön kuin amerikkalaisten, jotka keskittyvät kuuntelemisessaan enemmän puhujaan ja viestintäsuhteeseen - , molemmissa kulttuuriryhmissä juristit käyttävät runsaasti näitä hiljaiseen tietoon perustuvia itsesäätelystrategioita päästäkseen optimaaliseen kuuntelemistulokseen. On todennäköistä, että tämä tulos eli kuuntelemisen ymmärtäminen dialogisena prosessina, jolla voi vaikuttaa ammatilliseen viestintäsuhteeseen ja optimaaliseen työtulokseen pääsemiseen, on yleistettävissä myös muihin ammattiryhmiin kuin juristeihin.

Vaikka relationaalista dialektiikkaa ei tiettävästi olekaan aikaisemmin käytetty ammatillisissa viestintäsuhteissa tapahtuvan kuuntelemisen analysointiin, näissä suhteissa esiintyvät jännitteet liittyvät paitsi viestin tuottamiseen myös sen vastaanottamiseen. Tämän tutkimuksen tulosten mukaan nämä jännitteet olivat paitsi viestijöiden välisiä myös kuuntelijan sisäisiä jännitteitä. Tämä näkyi esimerkiksi siinä, että tuomarien mukaan heidän kuuntelemiseensa eniten vaikuttava vuorovaikutussuhteen jännite rakentui, kun he toisaalta halusivat säilyttää autonomisen aseman kuuntelijana ja toisaalta taas luoda vuorovaikutussuhdetta viestijäkumppaniin. Tämä tulos viittaa siihen, että kun institutionaalinen tehtävä ja henkilökohtainen kiinnostus työhön sekoittuvat, dialogisen kuuntelemisen tarve korostuu. Merkittävin sisäinen jännite tuomareiden mukaan syntyi, kun he aktiivisesti, joskin usein tiedostamattaan, vertasivat omaa tosiasiallista 
kuuntelemistaan siihen ideaaliin, joka heillä oli tuomarin kuuntelemisosaamisesta. Vaikuttaakin siltä, että juristien kuuntelemisorientaatio on kaksijakoinen: kun he ajattelevat tapoja, joilla kuuntelemista voi parantaa, he keskittyvät itseensä, mutta kun he ajattelevat kuuntelemista vuorovaikutuksellisena prosessina, he keskittyvät viestintäkumppaniinsa ja samastuvat tämän viestintään. Tämä osoittaa, että henkilökohtaisen toimijuuden kuuntelemisstrategioilla on mahdollista hallita jännitteitä, joita relationaalisen dialektiikan mukaan löytyy kaikista vuorovaikutussuhteista.

Tutkimuksen toista tavoitetta eli ammatillisen kuuntelemisosaamisen ulottuvuuksia ja rakennetta analysoitaessa huomattiin, ettei Wolvinin ja Coakleyn kuvailema perinteinen kuuntelemisosaamisen luokittelu ollut riittävä kuvaamaan sitä monipuolista kokonaisuutta, joka osoittaa ammatillisen kuuntelemisosaamisen koostuvan sekä yleisistä että ammattispesifeistä piirteistä. Ammatillinen konteksti tuo mukanaan paitsi ammatilliset viestintäsuhteet myös organisaatiokulttuurin ja kansallisen kulttuurin, joten perinteiseen kuuntelemisosaamiseen, joka kattaa vain kognitiiviset taidot, affektiivisen kapasiteetin ja kuuntelemiseen liittyvät yleiset käyttäytymismallit, lisättiin ammattispesifit viestintätaidot, dialoginen kuunteleminen ja henkilökohtainen ja kollektiivinen toimijuus. Perinteinen määritelmä ikään kuin luo yleisen perustan, ja muut elementit lisäävät ammatillisen näkökulman kuuntelemiseen. Luokittelu lienee yleistettävissä muihinkin ammattiryhmiin, sillä ammatillisen kuuntelemisosaamisen voidaan ajatella rakentuvan samalla tavalla ammattiryhmästä huolimatta, vaikka elementtien sisällöissä voi olla vaihtelua ammatista riippuen. Tutkimuksessa havaittiin myös, että mitä selkeämmin juristit tiesivät, millaista kuuntelemiskäyttäytymistä heidän ammatilliset tavoitteensa heiltä odottivat, sitä valmiimpia he kokivat olevansa vastaamaan ammattinsa asettamiin haasteisiin. Tämä selkeästi lisäsi heidän minäpystyvyytensä kokemusta.

Yllättävänä tuloksena voidaan pitää kuuntelemisosaamisen ulottuvuuksien hierarkkisuutta. Se paljastui, kun tutkimusaineistoa analysoitiin ammatillisesta näkökulmasta. Perinteisesti eri ulottuvuuksien välillä ei ole tehty eroa, vaan kontekstuaalisen, kognitiivisen, affektiivisen, eettisen ja käyttäytymisen ulottuvuuksien on kaikkien katsottu vaikuttavan yhtä paljon kuuntelemisosaamiseen. Tämän tutkimuksen tulokset osoittivat selvästi, että kontekstuaalisen ulottuvuuden vaikutus kaikkiin muihin ulottuvuuksiin oli merkittävä. Tämä kontekstuaalisen ulottuvuuden dominoiva vaikutus ei välttämättä ole yleistettävissä oikeudellisen kontekstin ulkopuolelle, vaan muissa ammattiryhmissä esimerkiksi käyttäytymi- 
sen tai eettisen ulottuvuuden vaikutus voi olla vahvin.

Tutkimuksen kolmantena tavoitteena oli hahmottaa dialogisen kuuntelemisen roolia ammatillisten vuorovaikutussuhteiden hallinnassa. Tarkastelun kohteeksi valittiin viime aikoina pinnalla olleen aktiivisen kuuntelemisen sijasta dialoginen kuunteleminen, koska sen soveltamista ammatilliseen kontekstiin ei ole juuri kartoitettu. Dialoginen kuunteleminen eroaa aktiivisesta kuuntelemisesta siinä, ettei se vaadi kuuntelijaa pitämään omia tunteitaan kokonaan sivussa kuunneltaessa vaan antaa mahdollisuuden pitää oma näkökulma mielessä puhujan viestiä tulkittaessa. Tämä on olennaista ammatillisen kuuntelemisen näkökulmasta, koska juristit eivät ole työssään niin sanottuja tyhjiä tauluja vaan ammattirooli ohjaa heidän kuuntelemistaan. Heidän on erittäin tärkeä varmistaa ammatillisessa viestinnässään, että olennainen informaatio tulee esiin ja että kaikki vuorovaikutuksen osapuolet ymmärtävät ne merkitykset, joita heidän keskinäisessä viestinnässään luodaan. Tulokset osoittivat, että sekä suomalaiset että amerikkalaiset juristit käyttävät dialogista kuuntelemista nimenomaan tässä tarkoituksessa. Kun he kuuntelevat dialogisesti, heidän on helpompi havaita vuorovaikutussuhteissa esiintyvät jännitteet ja olla aktiivinen toimija niiden ratkaisemissa ja hallinnassa käyttämällä dialektisia strategioita. On todennäköistä, että samanlainen lähestymistapa ammatillisiin vuorovaikutussuhteisiin toimisi myös muilla ammattialoilla.

Tutkimuksen viimeisenä tavoitteena oli kartoittaa minäpystyvyyden käyttöä subjektiivisen työhyvinvoinnin edistämisessä. Tulokset osoittavat, että työn tavoitteet ohjaavat sekä suomalaisten että amerikkalaisten juristien kuuntelemista, minkä johdosta voidaan sanoa, että heidän ammatillinen kuuntelemisensa nojaa vahvasti kuuntelijan itsesäätelyyn. Juristit näyttävät tulevan tietoisiksi tästä kuuntelemisensa piirteestä pohtiessaan omaa ammatillista kuuntelemistaan. Tehokas itsesäätely ja aktiivisen henkilökohtaisen toimijuuden käyttö kaikilla kuuntelemisen taksonomisilla tasoilla on voimaannuttava ja minäpystyvyyden tunnetta lisäävä kokemus, jolla on yhteys ammatillisiin onnistumisen kokemuksiin ja näin työhyvinvointia kohtentava vaikutus. Tehokas henkilökohtaisen toimijuuden käyttö ei ole ongelmatonta oikeudellisessa kontekstissa, sillä vuorovaikutusta oikeussalissa ohjaavat tiukat säännökset. Juristit kuitenkin soveltavat kuuntelemiseensa esimerkiksi itsereflektiota, tarkoituksellisuutta, ennalta harkintaa ja omaan toimintaansa reagointia, jotka kaikki ovat itsesäätelyn strategioita. Tämän voidaan nähdä osoittavan, että he pystyvät tarkkaan säännellyssä vuorovaikutusympäristössä huolehtimaan oman ammatillisen kuuntelemisensa kehittämisestä ja sen myötä omasta työssäjaksamisestaan. 
Kokonaisuudessaan tämän väitöskirjatutkimuksen tulokset osoittavat, että kuuntelija voi omalla toiminnallaan huomattavasti parantaa kuuntelemisensa tehokkuutta ja toiminnallisuutta sekä työn tavoitteisiin yltämistä ja näin ollen myönteisten minäpystyvyyteen, vuorovaikutukseen ja työn tavoitteisiin liittyvien kokemusten myötä kohentaa omaa työhyvinvointiaan. Tulosten mukaan jo se, että juristit pyrkivät kohti työnsä kannalta optimaalisinta kuuntelukäyttäytymistä ja kokevat näin kuuntelemisellaan tekevänsä jotain oman työhyvinvointinsa eteen, lisää heidän minäpystyvyytensä ja voimaantumisensa tunnetta ja sen myötä vaikuttaa myönteisesti heidän työtyytyväisyyteensä.

\section{Lopuksi}

On kiinnostavaa, että kuuntelemisosaamisella voidaan vaikuttaa työhyvinvointiin. Tämän väitöskirjatutkimuksen teoreettisena kontribuutiona voidaan pitää sitä, että sen tuloksista rakentuu malli, joka osoittaa, miten yksilö voi kohentaa omaa subjektiivista työhyvinvoinnin kokemustaan olemalla tietoisempi kuuntelemisosaamisensa ammattispesifeistä piirteistä ja dialogisesta kuuntelemisesta ja miten hän voi kartuttaa omaa voimaantumisen kokemustaan käyttämällä kuuntelemisosaamista työn tavoitteiden saavuttamiseen. Käytännössä tämä voisi siis tarkoittaa esimerkiksi sitä, että henkilö miettisi ensin, millaista hänen omaan ammattiinsa sisältyvä optimaalinen kuuntelu olisi. Sitten hän voisi pohtia, millaisia vuorovaikutussuhteita hänen ammatissaan on ja millaisia jännitteitä niissä esiintyy. Sitten hän voisi hyödyntää omaa toimijuuttaan, henkilökohtaisesti tai kollektiivisesti, ja valita ne strategiat, joilla hän pyrkii optimaaliseen kuuntelemiseen ja vuorovaikutussuhteiden jännitteiden hallintaan. Strategioiden onnistuneen soveltamisen jälkeen hän voisi tuntea, että minäpystyvyytensä avulla hän on saavuttanut työkuuntelemiselleen ja työtehtävälleen asettamansa tavoitteet, jolloin tuloksena olisi voimaannuttava lisääntyneen työhyvinvoinnin tunne. Tämän mallin arvoa lisää se, että se on sovellettavissa myös oikeudellisen kontekstin ulkopuolella ja toimii missä tahansa ammattikontekstissa. Se antaa eri alojen ammattilaisille keinoja kehittää omaa ammatillista kuuntelemisosaamistaan, kun kuuntelemisesta tulee mallintamisen avulla helpommin jäsennettävissä ja harjoitettavissa oleva viestinnän osa-alue.

Tämä väitöskirja myös osoittaa sen, että relationaalisen dialektiikan ja sosio-kognitiivisen teorian soveltaminen ammatilliseen viestintään onnistuu hyvin, vaikka niistä erityisesti relationaalista dialektiikkaa on perinteisesti käytetty lähinnä lähisuhteissa tapahtuvan viestinnän analysointiin. 
Väitöskirja myös osallistuu kuuntelemista ja työhyvinvointia koskevaan keskusteluun puheviestinnän, psykologian ja sosiologian näkökulmista ja lisää ymmärtämystä kuuntelemisen tärkeydestä ammatillisuuden rakentumisessa. Kuunteleminen ei koskaan ole pelkkää passiivista vastaanottoa, mutta parhaimmillaan se on dialoginen viestintäteko, jonka avulla on mahdollista vaikuttaa sekä omaan että viestintäkumppanin toimintaan. 